\title{
Jóindulatú pajzsmirigygöbök rádiófrekvenciás hőablatiós kezelése
}

\author{
Doros Attila dr. ${ }^{1,2}$ - Reismann Péter dr. ${ }^{3}$ - Huszty Gergely dr. ${ }^{1}$ \\ Somogyi Dóra dr. ${ }^{1}$ - Mohos Gábor dr. ${ }^{1}$ - Szabó Tamás dr. ${ }^{1,2}$ \\ Tőzsér Gellért dr. ${ }^{1,2}$. Deák Pál Ákos dr. ${ }^{1,2}$
}

\author{
${ }^{1}$ Semmelweis Egyetem, Általános Orvostudományi Kar, Transzplantációs és Sebészeti Klinika, Budapest \\ ${ }^{2}$ Premier Med Egészségközpont, Budapest \\ ${ }^{3}$ Semmelweis Egyetem, Általános Orvostudományi Kar, II. Belgyógyászati Klinika, Budapest
}

\begin{abstract}
Bevezetés: A jóindulatú pajzsmirigygöbök gyakori elváltozások, kezelést azonban ritkán igényelnek. Panaszokat okozó, gyorsan növekvő, túlmúködő göbök kezelésére a rádiófrekvenciás ablatio mint hőablatiós módszer hatékony alternatív lehetőség, melyet ezen indikációban hazánkban elsőként alkalmaztunk.

Célkitüzés: Ismertetjük a jóindulatú pajzsmirigygöbök rádiófrekvenciás ablatiós kezelési sajátosságait, fontosságát, és értékeljük saját klinikai eredményeinket.

Módszer: 2016. június és 2019. szeptember között 140 páciens 186 pajzsmirigygöbét kezeltük a páciensek kiválasztását követően. A beavatkozások előtt és után meghatároztuk a kezelt göbök térfogatát, legnagyobb átmérőjét és a térfogatcsökkenést a vizsgált időszakban. Betegeinket legalább fél évig utánkövettük, az átlagos követési idő 12,5 \pm 5,9 hónap volt.

Eredmények: A kontrollvizsgálatok során kapott eredmények alapján az elváltozások mérete és erezettsége csökkent. Az átlagos térfogatcsökkenés 44,7 \pm 17,6\% volt az első hónap végére és 72,9 \pm 17,9\% a hatodik hónap után. Összesen 3 minor szövődményt észleltünk.

Következtetés: A rádiófrekvenciás ablatio a jóindulatú pajzsmirigygöbök kezelésére jól használható, hatékony eljárás, mely válogatott esetekben a sebészi kezelés értékes alternatívája. Orv Hetil. 2020; 161(27): 1131-1136.
\end{abstract}

Kulcsszavak: rádiófrekvenciás ablatio, hőablatio, pajzsmirigygöb, ultrahang

\section{Treatment of benign thyroid nodules by radiofrequency thermal ablation}

Introduction: Benign thyroid nodules are frequent findings in imaging studies, most of the time not requiring any intervention. Treatment is usually started when nodules increase in size, the patient becomes symptomatic or clinically relevant hyperthyroidism develops. Thermoablation is an effective alternative modality. In Hungary, our team has pioneered these interventions using radiofrequency ablation for decreasing the size of the nodules.

Aim: We are presenting our results showing the effectiveness of this treatment after introducing the role, importance and technique of thermoablation in benign thyroid nodules.

Method: Between June of 2016 and September of 2019, 186 nodules of 140 patients were treated with radiofrequency ablation and had at least 6 months of follow up. The volume and diameter of all the ablated nodules were measured and calculated, then the decreases of these parameters were followed using ultrasonography. The mean follow-up time was $12.5 \pm 5.9$ months.

Results: The size measurements at the follow-up ultrasonography examinations showed a decrease in size and vascularity. The mean volume reduction was $44.7 \pm 17.6 \%$ at one-month post-treatment and $72.9 \pm 17.9 \%$ at 6 months There were 3 minor complications.

Conclusions: Radiofrequency ablation represents a feasible, effective, well tolerated method for outpatient treatment of benign thyroid nodules. This method is a valuable alternative to surgical treatments in selected cases.

Keywords: radiofrequency ablation, thermal ablation, thyroid nodules, ultrasound

Doros A, Reismann P, Huszty G, Somogyi D, Mohos G, Szabó T, Tőzsér G, Deák PÁ. [Treatment of benign thyroid nodules by radiofrequency thermal ablation]. Orv Hetil. 2020; 161(27): 1131-1136.

(Beérkezett: 2020. január 20.; elfogadva: 2020. március 22.) 


\section{Rövidítések}

$\mathrm{G}=$ gauge $;$ PEI = percutan etanolos infiltráció; $\mathrm{RFA}=$ rádiófrekvenciás ablatio; $\mathrm{UH}=$ ultrahang

A daganatok magas hőmérsékleten történő roncsolására utaló leletek már az ősidőktől rendelkezésre állnak [1]. A modern orvoslásban számos területen használnak hőhatást daganatok pusztítására, kóros múködésű szövetek kezelésére. Ugyanilyen elterjedt a különböző vegyi anyagokkal végzett szövetroncsolás, valamint a szöveti tulajdonságok megváltoztatása. A fenti beavatkozások és egyéb, minimálisan invazív technikák kifejlesztésében és bevezetésében a mintegy 40-50 éves múltra visszatekintő intervenciós radiológia úttörő szerepet játszik [2]. A hőenergia generálásán alapuló technikák közül a legelterjedtebb eljárás a rádiófrekvenciás ablatio (RFA). Az RFA esetében egy speciálisan kialakított tü- és földelőelektróda között áramló elektromágneses energia a tú környezetében rezgésre készteti a vízmolekulákat. Az így létrejött súrlódási hő a környező fehérjék koagulációját okozza. Az ablatiós zóna a behatási idő és a leadott energia meghatározásával meglehetősen pontosan kiszámítható, tervezhető kiterjedésben [3-5]. A módszert rosszindulatú májdaganatok kezelésére kezdték széles körben sikeresen alkalmazni, később jóindulatú eltérések kezelésére is sor került [6-8]. Az egyik ilyen sikertörténet a strumagöbök hőablatiós kezelése, melyet világszerte számos centrumban RFA-val végeznek.

A jóindulatú pajzsmirigygöbök a legtöbb esetben nem igényelnek kezelést. Méretük, növekedésük, szerkezetváltozásuk, citológiai vizsgálatuk eredménye indikálhat aktívabb terápiás hozzáállást [9]. A jelenleg alkalmazott hagyományos és videoasszisztált mütéti megoldások javallatai a következők:

a) igazolt malignitás vagy annak alapos gyanúja;

b) kompressziós tünetek;

c) ritkábban kozmetikai indikációk;

d) hyperthyreoid strumában és Graves-betegségben a radiojód-kezelés alternatívájaként.

A nagy, tünetmentes, euthyreoid göbök a malignitás gyanúja nélkül, illetve izotópvizsgálattal „hideg göbnek” diagnosztizált elváltozások a rosszindulatúság igazolása nélkül nem tekinthetők egyértelmû mütéti indikációnak $[10,11]$.

A benignus strumagöbök kezelésére az elmúlt 20 évben számos alternatív - nem sebészi - roncsolómódszert fejlesztettek ki. A kémiai ablatio során 96\%-os alkoholt fecskendeznek a göbbe. Ez az ambuláns beavatkozás a leginkább cystosus göbök esetén eredményes, a tartós regresszióhoz ismételt kezelésekre lehet szükség. Gyakorlott kézben elfogadható mellékhatás- és szövődményráta jellemzi $[12,13]$. A hőablatiós kezelések - a rádiófrekvenciás hőablatio, a mikrohullámú termoterápia, a lézer indukálta termoterápia, a cryoablatio és a magas energiájú fókuszált ultrahangos kezelés - közül a cryoablatiós kezelés nem, a mikrohullámú hőablatio pedig egyelőre csak korlátozottan játszik szerepet ezen a területen, bár az utóbbi térnyerése szembeötlő ebben az indikációban is. Az ezen a területen ez idáig csak marginális szereppel bíró fókuszált ultrahangos szövetroncsolás előnye, hogy a szervezetbe való - szúrással-vágással történő - behatolásra nincs szükség: a speciális kialakítású kezelőfej egy pár milliméteres foltba koncentrálja az energiát, és itt komplex, hő- és kavitációs hatással roncsol, majd újabb pontba koncentrálva apró lépésekben kezeli a kóros elváltozást [14]. A többi említett módszer mindegyikében tût, tûelektródát/antennát szúrunk be a kezelni kívánt szövetbe, és azon energiát juttatunk be. Mindez ultrahangvezérléssel, folyamatos követéssel történik. A hazánkban elérhető rádiófrekvenciás strumagöbablatióhoz az úgynevezett „moving-shot” technikát alkalmazzuk [15, 16]. A módszer lényege, hogy folyamatos vagy szakaszos üzemmódban adagoljuk az energiát a kezelni kívánt szövetmasszába, a tû állandó repozicionálása mellett. A kezeléshez folyamatos ultrahangos követés szükséges, melynek segítségével számos kis, egymással átfedésben lévő ablatiós zónát hozunk létre, koagulálva a göböt és az azt ellátó ereket.

\section{Beteg és módszer}

A benignus strumagöbök hőablatiós kezelését - a sebészi kezelés alternatívájaként - az alábbi javallatok szerint végeztük:

- szövettanilag jóindulatú, szolid vagy túlnyomóan szolid göbök, amelyeknél a benignitást két külön citológiai vizsgálat vagy egy, 18 G-s tûvel végzett 'core' (vastagtûs) biopszia igazolta;

- a göb komoly panaszt (idegentest-érzés, nyaki diszkomfort, fájdalom) okozott a betegnek;

- kifelé domborodó göbök, amelyek esztétikai problémát okoztak;

- gyorsan növekvő - de egyértelműen jóindulatú - göbök (50\% térfogat-növekedés volt egy év alatt);

- a betegnek jelentős lelki terhet jelentett a jóindulatú göb rendszeres kontrollja, a félelem a napi életében hátráltatja;

- a beteg visszautasította a mútétet, esetleg társult betegségei vagy többszörös nyaki operációi miatt a mütét nem volt kivitelezhető.

A kontraindikációk köre az alábbi volt:

- ellenoldali hangszalag-rendellenesség (bénulás) - minden esetben egyedi elbírálást igényelt;

- nem korrigálható véralvadási zavar;

- súlyos szív- vagy tüdőbetegség [8].

2014-ben és 2015-ben, hazánkban úttörőként, egyetemi klinikán elvégzett első és második pajzsmirigy rádiófrekvenciás kezelés (RFA) után 2016 nyarán indult el budapesti magánszolgáltatónál a rendszeres beavatkozások sora. A konzultációra jelentkező páciensek kiválasztását endokrinológiai, szövettani és fül-orr-gégészeti kivizsgálás előzte meg. A szövettani kivizsgálást - Baek javaslata alapján - egy vastagtüs biopszia vagy két, egy- 
mástól eltérő időpontban végzett citológia által igazolt benignitás (colloid struma, illetve adenoma) és mindezzel egybehangzó ultrahang-morfológia jelentette [17]. A vizsgálati időszakban kezelt göbök maximális átmérője elérte a $9 \mathrm{~cm}$ - $\mathrm{t}$, térfogata a $200 \mathrm{ml}$ - $\mathrm{t}$.

A nagyobb (általában $3 \mathrm{~cm}$-nél nagyobb) göbök esetén feltételeztük, hogy az elváltozások teljes térfogatát nem lehet majd egy alkalommal megfelelően kezelni, de a térfogatcsökkenés mértékétől tettük függővé az ismételt kezelés szükségességét.

A beavatkozásokat steril (kiemelt kezelő) körülmények között, Mygen M-3004 (RF Medical Co., Szöul, Dél-Korea) generátorral végeztük, mely előre beállított, de szabadon módosítható programokat futtat, 35-80 W energiával, 5-70 perc kezelési idővel, 7 vagy $10 \mathrm{~mm}$-es aktív zónás, $18 \mathrm{G}$ átmérőjü túelektródával. Pácienseinket a beavatkozások alatt monitoroztuk, aneszteziológus minden beavatkozásnál jelen volt. A beavatkozásokat 1-3 ampulla $10 \mathrm{ml}$-es 1\%-os Lidocain (allergia esetén Ultracain) helyi érzéstelenítésben végeztük; pácienseink közül egyesek további nyugtató, fájdalomcsillapító gyógyszereket is kaptak (midazolám, fentanil).

Páciensek - demográfia: Az első beavatkozás 2016. 06. 15-én történt, az utolsó 2019. 09. 04-én. A két időpont között eltelt időszakban 27l RFA-kezelés történt, melynek során 231 páciens 345 göbét kezeltük. A páciensek közül 184 nő, 47 férfi. A páciensek átlagéletkora a beavatkozáskor 48,8 $\pm 12,0$ év volt.

$\mathrm{Az}$ adatok feldolgozásakor csak azokat a pácienseket vettük figyelembe, akiknél legalább fél év utánkövetésre volt lehetőség. Így összesen 140 páciens 186 strumagöbe került be a tanulmányba.

A göbök adatai: A legtöbb kezelt göb egy páciensnél 4 db volt, rajta kívül alkalmanként maximum 3 göböt kezeltünk. Multiplex kezelt göb esetén arra törekedtünk, hogy csak azonos lebenyben és az isthmusban levő gö- böket kezeljük, 5 esetben azonban különböző lebenyekben elhelyezkedő göböket is kezeltünk. Általában a további képletek kezelésére második ülésben került sor. Az elváltozások többségükben a lebenyekben - azaz nem isthmicusan - helyezkedtek el, egyenlő arányban elosztva. 14 isthmicus göböt kezeltünk a vizsgált időszakban. A jobb és bal oldali göbök közül kezeltünk olyan elváltozásokat is, amelyek részben substernalis terjedést is mutattak. A göbök a szerkezetüket tekintve változatosak voltak, többségükben echószegények vagy izoechogének, emellett cysticus, vegyes és részben cysticus göbök esetén is végeztünk beavatkozásokat (1. és 2. ábra). A göbök térfogata $24,5 \pm 31,4 \mathrm{~cm}^{3}$ volt, a legkisebb göböt $0,9 \mathrm{~cm}^{3}$, a legnagyobbat $208,8 \mathrm{~cm}^{3}$ nagyságúnak mértük. A térfogatot minden göb esetében a következő képlettel számoltuk: $\mathrm{V}=\pi \mathrm{abc} / 6$ (ahol „V” a térfogat, „a” a legnagyobb átmérő, „b” és „c” a két másik merőleges átmérő) [15]. A göbök átlagos legnagyobb átmérôje $4,1 \mathrm{~cm}$ volt. A legnagyobb átmérőjű göb $9,3 \mathrm{~cm}$, a legkisebb 1,7 cm nagyságot ért el (1. táblázat).

A beavatkozás után a helyszínen kialakított pihenőágyakon 2-4 órás obszervációt végeztünk, a kezelt területet zselépárnával hűtöttük. A megfigyelési idő végeztével a páciens pépes táplálékot fogyasztott, és ivott; amennyiben semmilyen panasza nem volt, további pihenésre otthonába távozott. Aktív, szokásos életvitelét akár másnap folytathatta - néhány napig nonszteroid gyulladáscsökkentő alkalmazására is szükség volt egyeseknél.

Utánkövetés: Pácienseink követése ultrahangvizsgálattal történt. Az átlagos követési idő $12,5 \pm 5,9$ (6,1-30,4) hónap volt. A pajzsmirigygöbök térfogatát, legnagyobb átmérőjét és erezettségét ugyanazon módszerrel határoztuk meg a beavatkozás előtt és után. A térfogatcsökkenést a kezdeti térfogat és a kontrollvizsgálatokon mérhető térfogat különbsége alapján a következőképpen számoltuk: térfogatcsökkenés = ([kezdeti térfogat - a

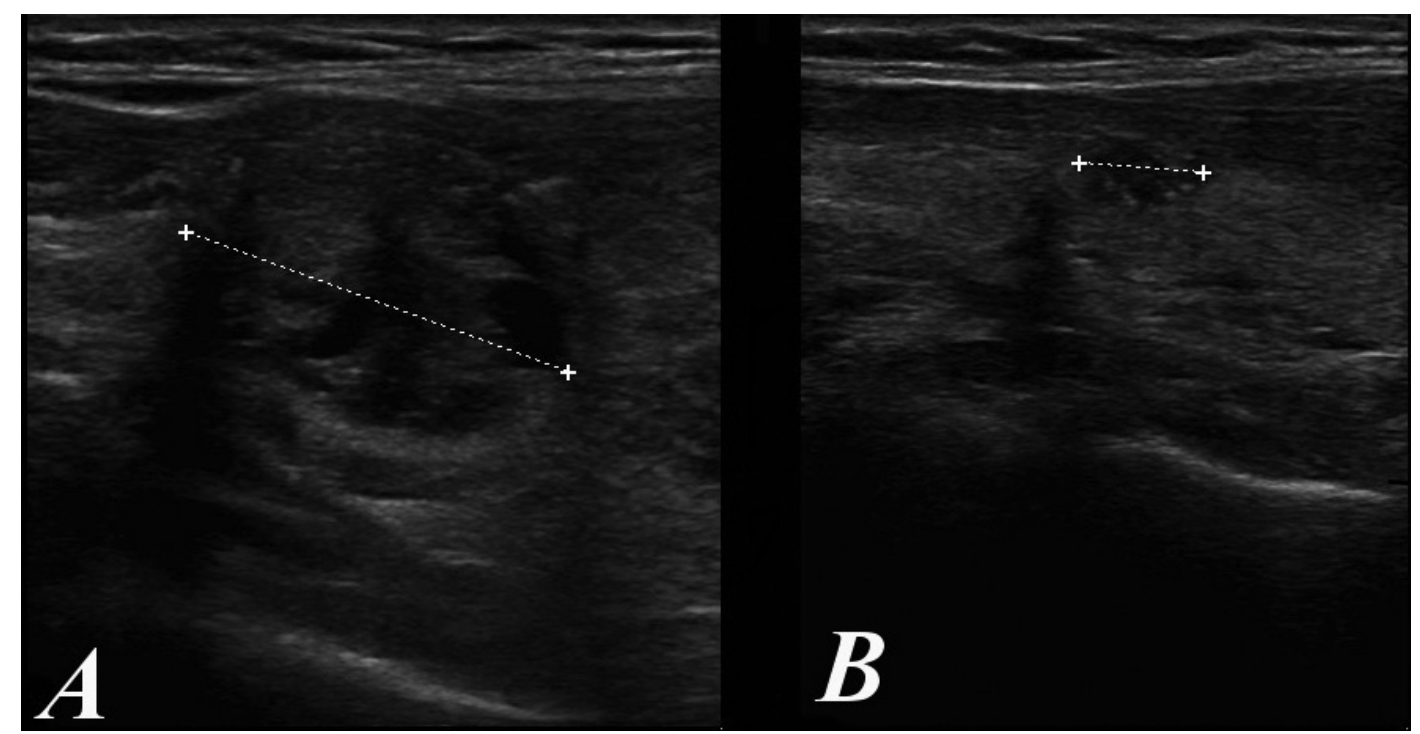




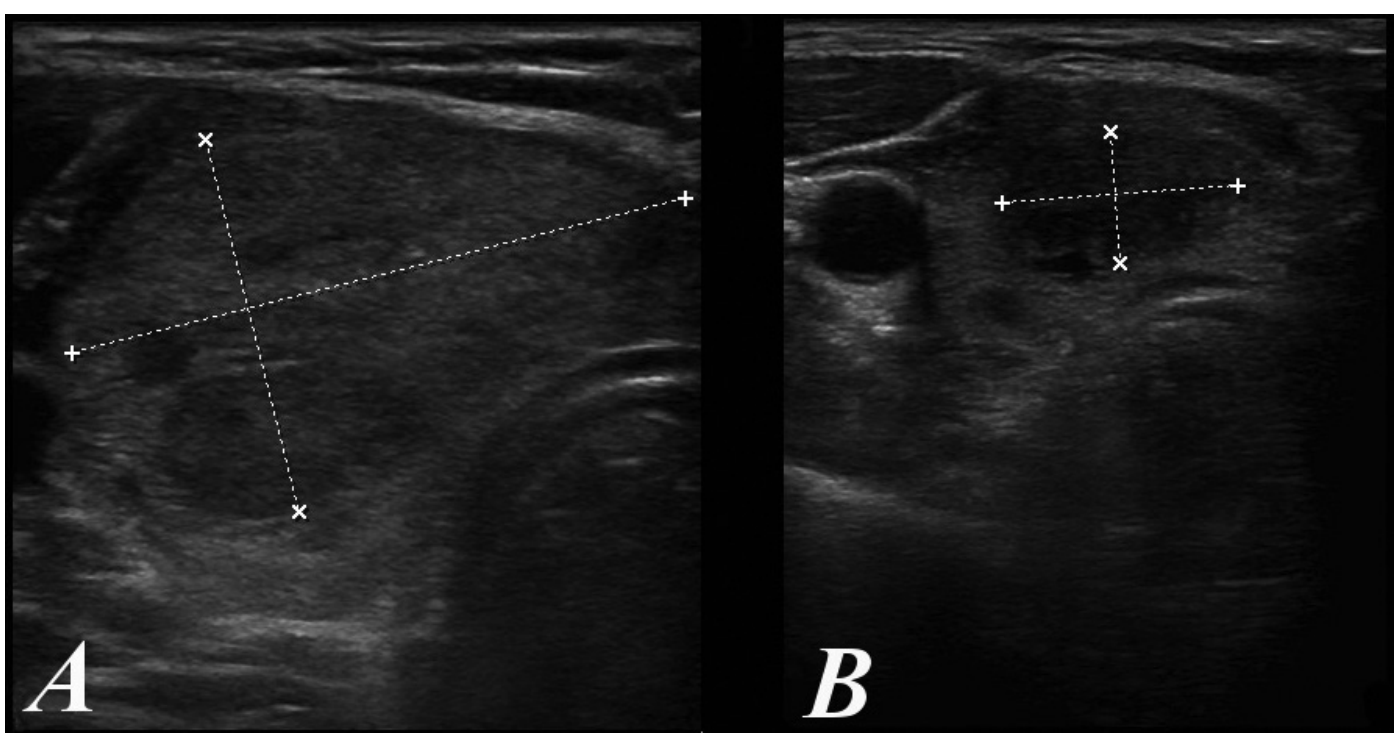

2. ábra | A) Szolid göb kezelés előtt (keresztmetszet). B) Szolid göb kezelés után (keresztmetszet), kezelés után 12 hónappal jelentés méretcsökkenés

kontrollvizsgálaton mért térfogat $]$ × 100) / kezdeti térfogat [18]. Terápiás sikerként a kontrollvizsgálatok során észlelt folyamatos regressziót értékeltük. A kezelések után 1, 3, 6 és 12 hónappal, majd - megfelelő eredmény esetén - évente végzünk ultrahangos ellenőrzést. Az ebben a vizsgálatban szereplő betegeinket legalább 6 hónapig követtük, ez idő alatt háromszor végeztünk ultrahangvizsgálatot, és történt endokrinológiai ellenőrzés.

\section{Eredmények}

A pajzsmirigygöbök térfogata a vizsgált időszakban szignifikánsan csökkent, a kezdeti $24,5 \pm 31,4 \mathrm{~cm}^{3}$-ról a beavatkozás utáni elsố hónapot követően $14,9 \pm 22,8 \mathrm{~cm}^{3}$ re, fél év elteltével 7,6 $\pm 11,9 \mathrm{~cm}^{3}-\mathrm{re}$. Az átlagos térfogatcsökkenés $44,7 \pm 17,6 \%$ volt az első hónap végére és $72,9 \pm 17,9 \%$ a hatodik hónap után (3. ábra).

Szövődmény a 140 páciens közül 3 esetben alakult ki: egy esetben vérömleny a beavatkozást követően, mely spontán felszívódott; egy esetben parciálisan ablált nagy göbben felülfertőződés alakult ki, mely konzervatív és minimálisan invazív kezelést követôen ismételt ablatio után rendeződött, hospitalizálást nem igényelt; egy esetben pedig korábbi pajzsmirigymútét után már érintett hangszalagmozgás mellett átmeneti, spontán szúnő rekedtség jelentkezett. A rekedtség oka ilyen helyzetben

1. táblázat |A páciensek $(\mathrm{n}=140)$ és a göbök $(\mathrm{n}=186)$ jellemzői

\begin{tabular}{ll}
\hline Jellemző & Rádiófrekvenciás ablatio \\
\hline Életkor (évek) & $48,3 \pm 12,5(22-75)$ \\
Nem (férfi : nő) & $27: 113$ \\
A göb átmérője $(\mathrm{cm})$ & $4,1 \pm 1,8(1,7-9,3)$ \\
A göb térfogata $\left(\mathrm{cm}^{3}\right)$ & $24,5 \pm 31,4(0,9-208,8)$ \\
Átlagos követési idő (hónap) & $12,5 \pm 5,9(6,1 \pm 30,4)$ \\
\hline
\end{tabular}

csak feltételezhető, a közvetlen hőhatás valószínúsége elhanyagolható - a hőkkezelés hatására kialakult egyoldali ödéma kompressziós hatása lehet az oka. Más súlyos vagy enyhe szövődményt nem tapasztaltunk.

\section{Megbeszélés}

A pajzsmirigyben gyakoriak a göbképződéssel járó elváltozások. A göbök többsége panaszt nem okoz, meglétükre véletlenszerúen derül fény. A legtöbb esetben benignus elváltozásokról beszélünk, melyek esetén időszakos ultrahangos ellenőrzés és laborvizsgálat elegendő. A panaszokat okozó, a beteg hétköznapi életében gondot jelentő (kompresszió, túlmúködés) és nem utolsósorban malignus göbök esetén kezelés szükséges. A rosszindulatú folyamatoknál ez egyértelmúen mútétet jelent, a legtöbbször lobectomia vagy thyreoidectomia

Térfogatcsökkenés

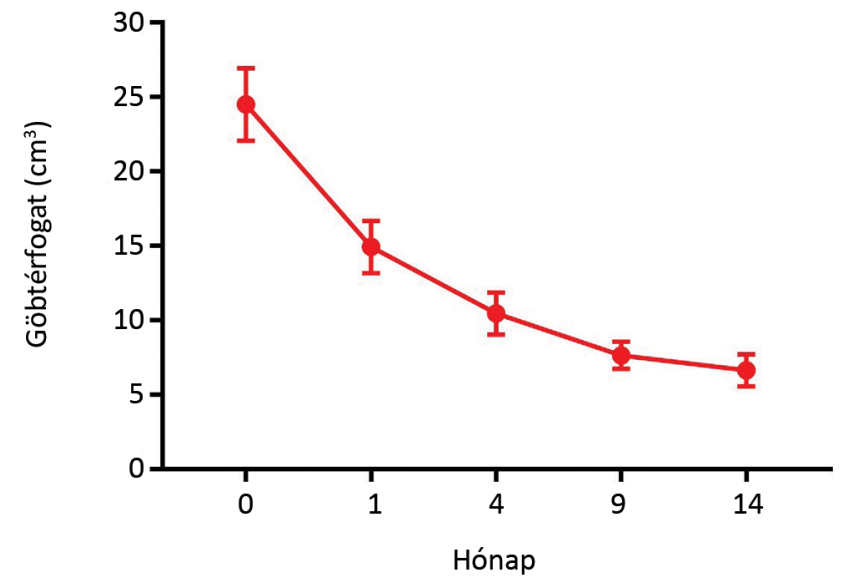

3. ábra A kezelt göbök átlagos térfogatcsökkenése a beavatkozásokat követően 
elvégzését. A benignus göbök kezelésében a levotiroxin vagy jód tartós adása nem mutatott szignifikáns méretbeli csökkenést [19]. A I131-radiojód-kezelés sikere csak nagy mennyiségű jódizotóp adását követően látható, viszonylag hosszú idő után [20]. A leggyakrabban alkalmazott beavatkozás hagyományosan a mútéti reszekció. Manapság az operatív terápia mellett helyet kapnak a minimálinvazív ablatiós modalitások is: ez döntően cysticus pajzsmirigygöb esetében percutan etanolos infiltrációt (PEI), dominánsan szolid göb esetében hőablatiót jelent. Hazánkban az RFA alkalmazása terjedt el, de nemzetközi munkacsoportok lézerrel, mikrohullámmal és fókuszált ultrahanggal végzett ablatiókkal is jó eredményeket értek el $[5,14]$.

A jelen közlemény az első hazai eredményeket mutatta be a benignus pajzsmirigygöbök RFA-kezeléséról. A feldolgozott időszakban 186 benignus strumagöb RFA-kezelését végeztük el. A beavatkozások előtt és után és minden egyes kontrollvizsgálat alkalmával UH-vizsgálatot végeztünk. Az eredményesség igazolásához a göbök térfogatának és legnagyobb átmérőjének csökkenését vettük figyelembe, emellett az erezettséget is vizsgáltuk. A kapott eredményeket öt nemzetközi vizsgálat eredményeivel hasonlítottuk össze, melyek közül kisebb és nagyobb elemszámú is volt a saját vizsgálatunkhoz képest. Az utánkövetés időtartama néhány publikáció esetében hasonló a miénkhez, néhányan azonban az általunk vizsgáltnál hosszabb ideig folytatták a kontrollálást. Eredményeink lényegében megegyeznek a nemzetközi eredményekkel (4. ábra) [16, 21-24].

A benignus pajzsmirigygöbök RFA-beavatkozása ebben az indikációban hazánkban jelenleg csak magánegészségügyi ellátás keretein belül vehető igénybe. Ezen minimálinvazív beavatkozás célja az, hogy a mútéttől tartó, azt valamilyen személyes okból nem vállaló, illetve arra alkalmatlan betegek számára terápiás alternatívát nyújtson, a személyre szabott orvoslást tökéletesebbé tegye. Az ablatiós eljárások a mútéti beavatkozásokkal szemben csupán a göb méretbeli redukcióját érik el - ebből következik, hogy a göbképződési hajlam is megmarad (ugyanúgy, mint a részleges sebészi reszekciók után), így számolhatunk a pajzsmirigyben új göbök megjelenésével. Ugyanakkor a göbök célzott kezelése, ha nem túlmúködő adenomáról van szó, nem változtatja meg a pajzsmirigyfunkciót. Toxikus adenoma esetén a túlmüködés a hőablatióval jól kezelhető. A sebészi eljárások közül manapság elsődlegesek a lobectomia, (majdnem) teljes thyreoidectomia beavatkozások. Ennek oka, hogy lebeny- vagy szerveltávolítást követően nem kell recidívával számolni, és így elkerülhető egy esetleges másodlagos mütét okozta magasabb szövődményarány. A hőablatiós beavatkozásokra a mútétnél kisebb szövődményráta jellemző, melyet egy dél-koreai tanulmány is megerősít: ebben 200, mütéten átesett, valamint 200, RFA-kezelt beteg adatait hasonlították össze [25]. Azt is meg kell említeni, hogy a (majdnem) teljes thyreoidectomia elkerülhetetlen hatása a posztoperatív, tartós hypothyreosis, amely miatt a betegek élethossziglan hormonpótló (levotiroxin-) kezelésre szorulnak [26, 27]. Erre RFA-t követően nincs szükség. Az RFA további előnye, hogy helyi érzéstelenítésben, egy-két tűszúrásnyi intervencióval végezhető, így az altatás - minden szövődményével és nehézségével együtt - elkerülhető. Ez különösképp az egyéb társbetegséggel élő betegek esetén fontos. A posztoperatív időszak lerövidülése, a beteg korábbi munkába állása az RFA további előnyeihez sorolható [25]. A módszer az esztétikai eredmény tekintetében is előnyösebb a mütéttel szemben, hiszen nem jár mütéti heggel, bár a térfogatcsökkenés nem azonnali.

\section{Következtetés}

A cikkünkben leírt eljárást még kevéssé ismerik hazánkban. Megismertetésének első lépése eredményeink bemutatása, melyek a nemzetközi eredményekkel összhangban az eljárás sikerességét jelzik. A benignus

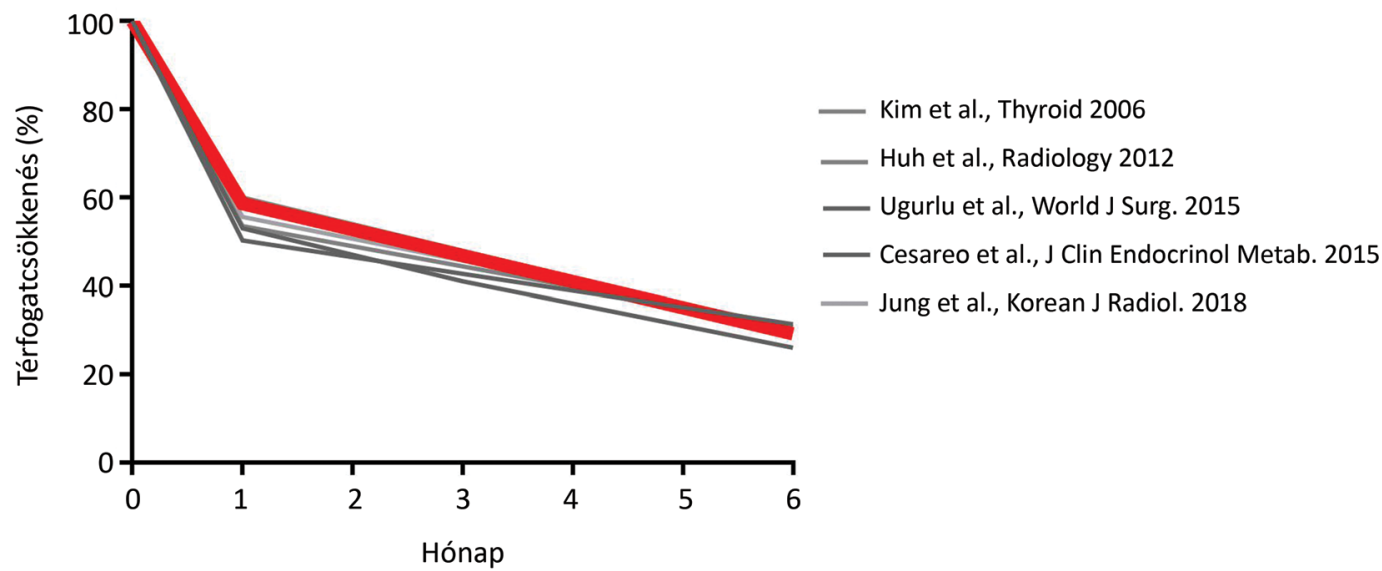

4. ábra

RFA utáni térfogatcsökkenés. Öt nemzetközi tanulmány és a saját eredményeink (piros színnel) összehasonlítása. Eredményeink megegyeznek a nemzetköziekkel

RFA = rádiófrekvenciás ablatio 
strumagöbök RFA-kezelésének létjogosultsága a jövőben nem lehet kérdés. A módszer medicinában betöltött helyének és szerepének kialakulása többszakmás együttmúködéssel és a betegek érdekeinek figyelembevételével napjainkban is zajlik.

Anyagi támogatás: A tanulmány elkészítése anyagi támogatásban nem részesült.

Szerzői munkamegosztás: D. P. Á., M. G., D. A.: A szöveges és a képi tartalom összeállítása. S. D., M. G.: Az adatok gyúijtése, feldolgozása. R. P., H. G., Sz. T., T. G, D. P. Á., D. A.: A tartalom multidiszciplináris felülvizsgálata. A cikk végleges változatát valamennyi szerző elolvasta és jóváhagyta.

Érdekeltségek: A szerzőknek nincsenek érdekeltségeik.

\section{Irodalom}

[1] Bánsághi Z. The role of radiofrequency ablation in the treatment of malignant tumors. Openings and limits. [A rádiófrekvenciás ablatio helye a malignus daganatok kezelésében. Lehetôségek és korlátok.] Magy Seb. 2008; 61: 59-64. [Hungarian]

[2] Horkan C, Goldberg SN. History, principles, and techniques of radiofrequency ablation. Semin Intervent Radiol. 2003; 20: 253-268.

[3] Nixon IJ, Angelos P, Shaha AR, et al. Image-guided chemical and thermal ablations for thyroid disease: review of efficacy and complications. Head Neck 2018; 40: 2103-2115.

[4] Barile A, Quarchioni S, Bruno F, et al. Interventional radiology of the thyroid gland: critical review and state of the art. Gland Surg. 2018; 7: 132-146.

[5] Gharib H, Hegedüs L, Pacella CM, et al. Clinical review: Nonsurgical, image-guided, minimally invasive therapy for thyroid nodules. J Clin Endocrinol Metab. 2013; 98: 3949-3957.

[6] Mayo SC, Pawlik TM. Thermal ablative therapies for secondary hepatic malignancies. Cancer J. 2010; 16: 111-117.

[7] Donadon M, Solbiati L, Dawson L, et al. Hepatocellular carcinoma: the role of interventional oncology. Liver Cancer 2016; 6 : 34-43.

[8] Deák PÁ, Korda DÁ, Doros A. Thermoablation therapy in the treatment of benign lesions. [Thermoablatiós lehetőségek a benignus térfoglaló képletek gyógyításában.] Orv Hetil. 2016; 157: 2040-2047. [Hungarian]

[9] Dean DS, Gharib H. Epidemiology of thyroid nodules. Best Pract Res Clin Endocrinol Metab. 2008; 22: 901-911.

[10] Bartsch DK, Luster M, Buhr HJ, et al. Indications for the surgical management of benign goiter in adults. Dtsch Arztebl Int. 2018; 115: 1-7. [Correction: Dtsch Arztebl Int. 2018; 115: 144.]

[11] Ésik O. By adhering to current practice guidelines, survival is improved in thyroid cancer: review of 24 papers about thyroid cancer published in English by Hungarian investigators in the past 20 years. [A korszerú szakmai irányelvek követésével javíthatók a pajzsmirigyrákos betegek túlélési esélyei: a pajzsmirigydaganatokról hazai kutatóktól az elmúlt 20 évben meg jelent 24 angol nyelvű közlemény áttekintése.] Orv Hetil. 2001; 142: 2431-2435. [Hungarian]

[12] Orlacchio A, Bolacchi F, Chegai F, et al. Comparative evaluation of percutaneous laser and radiofrequency ablation in patients with HCC smaller than $4 \mathrm{~cm}$. Radiol Med. 2014; 119: 298-308.

[13] Kim DW, Rho MH, Park HJ, et al. Ultrasonography-guided ethanol ablation of predominantly solid thyroid nodules: a preliminary study for factors that predict the outcome. Br J Radiol. 2012; 85: 930-936.

[14] Korkusuz Y, Kohlhase K, Gröner D, et al. Microwave ablation of symptomatic benign thyroid nodules: energy requirement per $\mathrm{ml}$ volume reduction. [Mikrowellenablation von symptomatischen, benignen Schilddrüsenknoten: Energiebedarf pro ml Volumenreduktion.] Rofo 2016; 188: 1054-1060. [German]

[15] Ha EJ, Baek JH, Lee JH. Moving-shot versus fixed electrode techniques for radiofrequency ablation: comparison in an ex-vivo bovine liver tissue model. Korean J Radiol. 2014; 15: 836-843.

[16] Jung SL, Baek JH, Lee JH, et al. Efficacy and safety of radiofrequency ablation for benign thyroid nodules: a prospective multicenter study. Korean J Radiol. 2018; 19: 167-174.

[17] Baek JH, Moon WJ, Kim YS, et al. Radiofrequency ablation for the treatment of autonomously functioning thyroid nodules. World J Surg. 2009; 33: 1971-1977.

[18] Lim HK, Lee JH, Ha EJ, et al. Radiofrequency ablation of benign non-functioning thyroid nodules: 4-year follow-up results for 111 patients. Eur Radiol. 2013; 23: 1044-1049.

[19] Grussendorf M, Reiners C, Paschke M, et al. Reduction of thyroid nodule volume by levothyroxine and iodine alone and in combination: a randomized, placebo-controlled trial. J Clin Endocrinol Metab. 2011; 96: 2786-2795.

[20] Ceccarelli C, Bencivelli W, Vitti P, et al. Outcome of radioiodine-131 therapy in hyperfunctioning thyroid nodules: a 20 years' retrospective study. Clin Endocrinol. 2005; 62: 331-335.

[21] Kim YS, Rhim H, Tae K, et al. Radiofrequency ablation of benign cold thyroid nodules: initial clinical experience. Thyroid 2006; 16: 361-367.

[22] Huh JY, Baek JH, Choi H, et al. Symptomatic benign thyroid nodules: efficacy of additional radiofrequency ablation treatment session - prospective randomized study. Radiology 2012; 263: 909-916.

[23] Ugurlu MU, Uprak K, Akpinar IN, et al. Radiofrequency ablation of benign symptomatic thyroid nodules: prospective safety and efficacy study. World J Surg. 2015; 39: 961-968.

[24] Cesareo R, Pasqualini V, Simeoni C, et al. Prospective study of effectiveness of ultrasound-guided radiofrequency ablation versus control group in patients affected by benign thyroid nodules. J Clin Endocrinol Metab. 2015; 100: 460-466.

[25] Che Y, Jin S, Shi C, et al. Treatment of benign thyroid nodules: comparison of surgery with radiofrequency ablation. Am J Neuroradiol. 2015 ; 36: 1321-1325.

[26] Leövey A. Nodular diseases of the thyroid gland. In: Leövey A, Nagy V, Paragh Gy, et al. (eds.) Handbook of endocrine and metabolic diseases. [A pajzsmirigy göbös megbetegedései. In: Leövey A, Nagy V, Paragh Gy, et al. (szerk.) Az endokrin és anyagcsere-betegségek gyakorlati kézikönyve.] Medicina Könyvkiadó, Budapest, 2016; pp. 162-172. [Hungarian]

[27] Larijani B, Pajouhi M, Bastanhagh MH, et al. Evaluation of suppressive therapy for cold thyroid nodules with levothyroxine: double-blind placebo-controlled clinical trial. Endocr Pract. $1999 ; 5: 251-256$

(Doros Attila dr., Budapest, Baross u. 23-25., 1082 e-mail: attiladoros41@gmail.com)

A cikk a Creative Commons Attribution 4.0 International License (https://creativecommons.org/licenses/by/4.0/) feltételei szerint publikált Open Access közlemény, melynek szellemében a cikk bármilyen médiumban szabadon felhasználható, megosztható és újraközölhetö, feltéve, hogy az eredeti szerző és a közlés helye, illetve a CC License linkje és az esetlegesen végrehajtott módositások feltüntetésre kerülnek. (SID_1) 